\title{
HUBUNGAN ANTARA MARKETING MIX DENGAN KEPUTUSAN PEMBELIAN SAYURAN HIDROPONIK DI KIOS GRANARI FRESH SEMARANG
}

\section{RELATIONSHIP BETWEEN MARKETING MIX WITH THE DECISION OF PURCHASING HYDROPHONIC VEGETABELS IN KIOS GRANARI FRESH SEMARANG}

\author{
Pandu Asmo Bangun ${ }^{1)}$ dan Bayu Nuswantara ${ }^{1)}$ \\ Fakultas Pertanian dan Bisnis, Universitas Kristen Satya Wacana \\ Email: 522015026@Student.uksw.edu
}

\begin{abstract}
ABSTRAK
Salah satu perusahaan dalam bidang agribisnis yang memproduksi sayuran hidroponik di Jawa Tengah adalah PT. Hidroponik Agrofarm Bandungan (HAB) yang berlokasi di Bandungan Jl. Mangoenkoesoemo, Ngasem, Bandungan Kabupaten Semarang. Tujuan Penelitian ini adalah untuk menganalisis hubungan antara Marketing mix dengan keputusan pembelian sayuran hidroponik di PT. HAB. Penelitian ini dilakukan pada bulan April - Mei 2019. Jenis penelitian ini adalah deskriptif kuantitatif, teknik pengambilan sampel menggunakan accidental sampling. Responden dalam penelitian ini sebanyak 50 konsumen Sayuran Hidroponik PT. HAB. Pengumpulan data diperoleh dengan wawancara, kuesioner, observasi dan studi pustaka. Teknik analisis data yang digunakan adalah korelasi rank spearman. Hasil penelitian ini menyatakan bahwa marketing mix memiliki hubungan yang signifikan terhadap keputusan pembelian sayuran hidroponik
\end{abstract}

Kata Kunci: marketing mix; pengambilan keputusan; sayuran hidroponik

\section{ABSTRACT}

One of the agribusiness companies that produce hydroponic vegeTabels in Central Java is PT. Hydroponics Agrofarm Bandungan (HAB) located in Bandungan Jl. Mangoenkoesoemo, Ngasem, Bandungan, Semarang Regency. The purpose of this study was to analyze the relationship between marketing mix with the purchase decision of hydroponic vegeTabels at PT. HAB. This research was conducted in April - May 2019. This type of research is quantitative descriptive, sampling techniques using accidental sampling. Respondents in this study were 50 consumers of VegeTabel Hydroponics at PT. HAB. Data collection was obtained by interview, questionnaire, observation and literature study. The data analysis technique used is the Spearman rank correlation. The results of this study stated that the marketing mix has a significant relationship to purchasing decisions for hydroponic vegetables.

Keywords: hydroponic decision making; marketing mix; vegetable 


\section{PENDAHULUAN}

Hidroponik secara harfiah berarti hydro $=$ air, dan phonic $=$ pengerjaan. Secara umum berarti sistem budidaya pertanian tanpa menggunakan tanah tetapi menggunakan air yang berisi larutan nutrisi. Budidaya hydroponic biasanya dilaksanakan di dalam rumah kaca (green house) untuk menjaga supaya pertumbuhan tanaman optimal dan benar-benar terlindung dari pengaruh unsur luar seperti hujan, hama penyakit dan iklim (Roidah, 2014).

Hidroponik merupakan metode yang ramah lingkungan karena tidak menggunakan pestisida. Sistem budidaya secara hidroponik sering diterapkan untuk mengatasi kekurangan lahan pertanian seperti di daerah perkotaan, dalam hal ini adalah tanaman sayuran. Sayuran hidroponik adalah sayuran yang ditanam tanpa menggunakan media tanam dari tanah melainkan menggunakan media tanam air yang mengandung campuran hara (Rosliani dan Sumarni, 2005).

Sementara itu keputusan pembelian merupakan suatu konsep perilaku pembeli di mana konsumen memutuskan untuk bertindak atau melakukan sesuatu dan dalam hal ini melakukan pembelian ataupun memanfaatkan produk atau jasa tertentu (Balawera, 2013).

Menurut Kotler (2000) bauran pemasaran adalah alat pemasaran yang digunakan untuk mencapai tujuan pemasaran. Sasaran meliputi item pemasaran yaitu price, product, promotion, dan place (4P) di mana semuanya itu diarahkan untuk menghasilkan omset penjualan yang maksimal atas produk yang dipasarkan dengan memberikan kepuasan pada para pelanggan.

Menurut Kotler dan Keller (2012) harga merupakan sejumlah nilai yang ditukarkan konsumen dengan manfaat dari memiliki atau menggunakan produk atau jasa yang nilainya ditetapkan oleh pembeli dan penjual melalui tawar menawar.

Produk adalah segala sesuatu yang dapat dipergunakan untuk memuaskan dan memenuhi kebutuhan dan keinginan konsumen yang diciptakan oleh produsen. Produk termasuk objek fisik, jasa, orang, tempat, organisasi dan ide. Produk 
merupakan segala sesuatu yang dapat ditawarkan produsen untuk diperhatikan, diminta, dicari, dibeli, digunakan atau dikonsumsi pasar sebagain pemenuhan kebutuhan atau keinginan pasar yang bersangkutan (Wangko, 2013).

Promosi adalah aktivitas yang mengomunikasikan keunggulan produk dan membujuk pelanggan sasaran untuk membelinya. Promosi juga merupakan salah satu kegiatan pemasaran yang penting bagi perusahaan dalam upaya mempertahankan eksistensi serta meningkatkan kualitas penjualan (Kotler, 2000).

Tempat adalah faktor yang sangat penting dalam bauran pemasaran (marketing mix). Pemilihan lokasi yang tepat akan membuat sebuah gerai lebih sukses dibandingkan dengan gerai lainnya apalagi lokasi penjualan sayuran hidroponik yang lokasi penjualannya merupakan saluran distribusi untuk mendapatkan konsumen dalam memutuskan pembelian terhadap produk sayuran hidroponik. Lokasi penjualan sangat menentukan karena merupakan domisili pedagang untuk memasarkan produknya (Mursid, 2014).

PT. Hidroponik Agrofarm Bandungan merupakan perusahaan yang bergerak di bidang agribisnis. Perusahaan tersebut didirikan pada tanggal 2 Juni 2016 dengan merek dagang "Hidroponik Agrofarm Bandungan The Farmhill'. Perusahaan ini dipimpin oleh direktur utama yaitu Richardus Indra Gunawan, S.TP., M.Si dan direktur operasional Petrus Adi Atmoko, S.

PT. Hidroponik Agrofarm Bandungan (HAB) menjadi salah satu perusahaan perseroan terbatas yang menghasilkan sayuran berkualitas prima dengan sistem budidaya secara hidroponik. Sejak Januari 2015 kebun HAB aktif beroperasi dengan memakai brand farmhill. Lahan yang dimiliki seluas 2,7 ha, dengan 10 buah green house masing-masing seluas $510 \mathrm{~m}^{2}$.

Di Indonesia sayuran hidroponik sudah dikenal oleh konsumen, walaupun demikian terdapat beberapa kendala dalam pembelian sayuran hidroponik. Hal ini merupakan konsekuensi akibat kurangnya 
pemahaman dan perencanaan tentang marketing mix yaitu 4P: harga, produk, promosi dan lokasi. Oleh karena itu sangat penting bagi PT. HAB untuk meningkatkan marketing mix dalam upaya menarik konsumen serta memenuhi kebutuhan dan harapan konsumen.

Berdasarkan uraian di atas maka dapat dirumuskan permasalahan penelitian yaitu bagaimanakah hubungan marketing mix dengan pengambilan keputusan pembelian sayuran hidroponik. Untuk menjawab permasalahan ini maka dilakukan penelitian di Granari Fresh Semarang PT. Hidroponik Agrofarm Bandungan (HAB)

\section{METODE PENELITIAN}

Penelitian ini dilaksanakan pada bulan April 2019. Tempat Penelitian berlokasi di Kios Granari Fresh Semarang PT. HAB. Pemilihan lokasi dilakukan secara sengaja (purposive) dengan pertimbangan di tempat tersebut banyak peminat yang membeli sayuran hidroponik.

Jenis penelitian yang digunakan adalah pendekatan deskriptif kuantitatif yang menekankan pada data numeric dan diolah dengan metode statistik. Teknik pengambilan sampel menggunakan non probability sampling dengan metode pengambilan sampelnya menggunakan accidental sampling. Teknik penentuan sampel berdasarkan ketentuan yaitu konsumen yang sengaja telah melakukan pembelian produk sayuran hidroponik di PT. HAB dan bertemu dengan peneliti dapat dijadikan sampel jika dipandang tepat. Pengambilan sampel sebanyak 50 responden.

Pengumpulan data yang digunakan adalah teknik wawancara, kuesioner, studi pustaka dan observasi. Instrumen pada penelitian ini menggunakan kuesioner berisi pertanyaan berbentuk checklist. Skala yang digunakan untuk pengukuran penelitian adalah skala likert dan untuk menguji pertanyaan pada kuesioner. Pengolahan data dilakukan dengan software computer Microsoft 2013 untuk input data menggunkan, SPSS versi 16.0 for windows untuk melakukan tiga pengujian yaitu: uji validitas, uji reliabilitas dan uji Korelasi Rank Spearman. 
Uji validitas merupakan salah satu usaha penting yang harus dilakukan guna mengukur kevalidan dan instrumen. Validitas atau kesahihan menunjukkan sejauh mana suatu alat ukur mampu mengukur apa yang ingin diukur (Sugiyono, 2014).

Setelah dilakukan uji validitas kemudian kuesioner juga perlu diuji reliabilitasnya. Reliabilitas adalah derajat ketepatan, ketelitian, keakuratan yang ditunjukkan oleh instrumen pengukuran (Husein, 2005). Uji ini digunakan untuk mengetahui sejauh mana hasil pengukuran dua kali atau lebih terhadap gejala yang sama dengan menggunakan alat pengukur yang sama pula (Siregar, 2010).

Uji korelasi digunakan untuk mengetahui kekuatan hubungan variabel $\mathrm{X}$ dengan variabel $\mathrm{Y}$. Hasil olah data diperoleh data ordinal sehingga analisis data menggunakan uji rank Spearman. Sugiyono (2014) mengatakan bahwa jenis data untuk korelasi rank spearman adalah data ordinal berasal dari sumber yang tidak sama, serta data dari kedua variabel tidak harus membentuk distribusi normal sehingga Sugiyono (2014) merumuskan rumus rank Spearman sebagai berikut :

$$
\rho=1-\frac{6 \sum b i^{2}}{n\left(n^{2}-1\right)}
$$

Hubungan dalam analisis korelasi rank Spearman menurut Sugiyono (2014) adalah sebagai berikut:

Tabel 1. Tingkat hubungan korelasi

\begin{tabular}{c|l}
\hline Koefesien korelasi & \multicolumn{1}{|c}{ Hubungan } \\
\hline $0,000-0,199$ & Sangat rendah \\
$0,200-0,399$ & Rendah \\
$0,400-0,599$ & Sedang \\
$0,600-0,799$ & Kuat \\
$0,800-1,000$ & Sangat kuat \\
\hline
\end{tabular}




\section{HASIL DAN PEMBAHASAN}

\section{Hasil Analisis Hubungan antara Marketing Mix (X) dengan Pengambilan Keputusan Pembelian Sayuran Hidroponik (Y)}

Tabel 2. Hubungan antara Harga $\left(\mathrm{X}_{1}\right)$, Produk $\left(\mathrm{X}_{2}\right)$, Promosi $\left(\mathrm{X}_{3}\right)$ dan Lokasi $\left(\mathrm{X}_{4}\right)$ dengan Pengambilan Keputusan Pembelian Sayuran Hidroponik (Y)

\begin{tabular}{|c|c|c|c|c|c|}
\hline No & Variabel & $\begin{array}{l}\text { Koefesien } \\
\text { Korelasi } \\
(\mathbf{R s})\end{array}$ & $\begin{array}{l}\text { sig. } \\
(< \\
0,05)\end{array}$ & $\begin{array}{l}\text { Keeratan } \\
\text { Hubungan }\end{array}$ & Keterangan \\
\hline 1 & $\operatorname{Harga}\left(\mathrm{X}_{1}\right)$ & $0,619^{* * *}$ & 0,000 & Kuat & Signifikan \\
\hline 2 & Produk $\left(\mathrm{X}_{2}\right)$ & $0,653^{* *}$ & 0,000 & Kuat & Signifikan \\
\hline 3 & Promosi $\left(\mathrm{X}_{3}\right)$ & $0,707^{* *}$ & 0,000 & Kuat & Signifikan \\
\hline 4 & Lokasi $\left(\mathrm{X}_{4}\right)$ & $0,741^{* *}$ & 0,000 & Kuat & Signifikan \\
\hline
\end{tabular}

Sumber : Data Primer diolah, 2019

Keterangan: ** Signifikan pada taraf kesalahan $\alpha=5 \%$

Hubungan Antara Harga $\left(\mathbf{X}_{1}\right)$ dengan Pengambilan Keputusan Pembelian Sayuran Hidroponik (Y)

Berdasarkan hasil analisis pada Tabel 2. dapat diketahui bahwa hasil uji nilai koefisien korelasi rank Spearman sebesar 0,619 dengan tanda positif dan signifikan sebesar 0,00 pada taraf kepercayaan $95 \%$ itu berarti terdapat hubungan yang sangat signifikan antara variabel harga dengan keputusan pembelian sayuran hidroponik. Koefesien korelasi variabel harga berada pada interval $0,600-0,799$ karena hasil dari pengujian korelasi berada di interval tersebut maka hubungan antara variabel harga dengan keputusan pembelian sayuran hidroponik dinyatakan mempunyai hubungan yang kuat. Hal ini sesuai dengan penelitian yang dilakukan oleh Angipora (2002) yang menyatakan bahwa harga memiliki pengaruh terhadap keputusan pembelian. Sejalan dengan faktor-faktor yang mempengaruhi permintaan menurut Ahmana dan Rohmana (2009) salah satunya adalah pendapatan konsumen. Semakin tinggi pendapatan seseorang 
maka semakin tinggi pula kemampuan seseorang untuk membeli barang.

Hubungan Antara Produk ( $\left.\mathbf{X}_{2}\right)$ dengan Pengambilan Keputusan Pembelian Sayuran Hidroponik (Y)

Berdasarkan hasil analisis pada Tabel 2. dapat diketahui bahwa hasil uji nilai koefisien korelasi rank Spearman sebesar 0,653 dengan tanda positif dan signifikan sebesar 0,00 pada taraf kepercayaan $95 \%$ itu berarti terdapat hubungan yang signifikan antara variabel produk dengan keputusan pembelian sayuran hidroponik. Koefesien korelasi variabel produk berada pada interval 0,600-0,799 karena hasil pengujian korelasi berada di interval tersebut maka hubungan antara variabel produk dengan keputusan pembelian sayuran hidroponik dikatakan kuat.

Hal ini sesuai dengan penelitian yang dilakukan oleh Ghanimata dan Mustofa (2012), bahwa variabel produk berpengaruh positif terhadap keputusan pembelian. Hal ini menyatakan bahwa penelitian ini sesuai dengan teori yang dikemukakan oleh Tjiptono (2007) menyatakan bahwa atribut produk adalah unsur- unsur produk yang dipandang penting oleh konsumen dan dijadikan dasar pengambilan keputusan pembelian bagi konsumen.

Tanda positif pada Tabel 2 menunjukan bahwa hubungan antara produk dengan keputusan pembelian sayuran hidroponik berbanding lurus yang berarti semakin bagus kualitas dari produk sayuran tersebut maka akan sangat kuat dan erat hubungan konsumen terhadap pengambilan keputusan pembelian sayuran hidroponik di PT. HAB.

\section{Hubungan Antara Promosi $\left(\mathbf{X}_{3}\right)$ dengan Pengambilan Keputusan Pembelian Sayuran Hidroponik (Y)}

Berdasarkan hasil analisis pada Tabel 2. diketahui bahwa hasil uji nilai koefisien korelasi rank Spearman sebesar 0,707 dengan tanda positif dan signifikan sebesar 0,00 pada taraf kepercayaan $95 \%$ itu berarti terdapat hubungan yang signifikan antara variabel promosi dengan keputusan pembelian sayuran hidroponik. Koefesien korelasi variabel promosi berada pada interval 0,600-0,799 karena hasil dari pengujian korelasi berada di interval tersebut maka 
hubungan antara variabel promosi dengan keputusan pembelian sayuran hidroponik dinyatakan kuat. Penelitian ini juga sejalan dengan teori Dwityanti (2008) yang menyatakan semakin tinggi daya tarik promosi maka semakin tinggi minat beli. Tanda positif pada Tabel 2 menunjukan bahwa hubungan antara promosi dengan keputusan pembelian sayuran hidroponik berbanding lurus yang berarti semakin kuat mempromosikan produk sayuran hidroponik tersebut maka akan semakin tinggi minat konsumen dalam melakukan pengambilan keputusan sayuran Hidroponik di PT.HAB

\section{Hubungan Antara Lokasi $\left(\mathbf{X}_{4}\right)$ dengan Pengambilan Keputusan Pembelian Sayuran Hidroponik (Y)}

Berdasarkan hasil analisis pada Tabel 2. diketahui bahwa hasil uji nilai koefisien korelasi rank spearman sebesar 0,707 dengan tanda positif dan signifikan sebesar 0,00 pada taraf kepercayaan $95 \%$ itu berarti terdapat hubungan yang signifikan antara variabel lokaso dengan keputusan pembelian sayuran hidroponik. Koefesien korelasi variabel lokasi berada pada interval $0,600-0,799$ karena hasil dari pengujian korelasi berada di interval tersebut maka hubungan antara variabel lokasi dengan keputusan pembelian sayuran hidroponik dinyatakan kuat.

Penelitian ini sejalan dengan teori Heizer dan Render (2006) menyatakan bahwa tujuan strategi lokasi adalah untuk memaksimalkan keuntungan perusahaan. Menentukan lokasi untuk setiap pelaku bisnis merupakan tugas yang sangat penting bagi pemasar.

Tanda positif pada Tabel 2 menyatakan bahwa hubungan antara lokasi dengan keputusan pembelian sayuran hidroponik berbanding lurus, yang berarti dengan melihat lokasi yang strategis maka semakin nyaman dan aman lokasi tersebut maka akan semakin kuat konsumen dalam melakukan pengambilan keputusan pembelian sayuran hidroponik di PT. HAB.

\section{KESIMPULAN DAN SARAN}

Kesimpulan

Terdapat hubungan yang signifikan antara Marketing Mix yang 
meliputi 4P yaitu: harga, produk, promosi dan lokasi dengan pengambilan keputusan pembelian sayuran hidroponik di PT. Hidroponik Agrofarm Bandungan. Setiap variabel memiliki hubungan yang kuat dan positif.

\section{Saran}

Saran untuk pihak PT. HAB yaitu untuk meningkatkan penjualan sayuran hidroponik di PT. Hidroponik Agrofarm Bandungan harus memperhatikan dan meningkatkan strategi pemasaran dari segi marketing mix.

\section{DAFTAR PUSTAKA}

Ahman, E. dan Y. Rohmana. 2009. Teori Ekonomi Mikro. Universitas Pendidikan Indonesia. Bandung.

Angipora, M., P. 2002. Dasar-Dasar Pemasaran. Penerbit PT. Raja Grafindo Persada. Jakarta.

Balawera, A. 2013. Green Marketing dan Corporate Responsibility Pengaruhnya terhadap Keputusan Pembelian Konsumen Melalui Minat Membeli Produk Organik di Freshmart Kota Manado. Jurnal Emba. 1 (4): 2117-2129.
Dwityanti, E. 2008. Analisis FaktorFaktor yang Mempengaruhi Minat Beli Konsumen terhadap Layanan Internet Banking Mandiri Studi Kasus pada Karyawan Departemen Pekerjaan Umum Jakarta. Masters Thesis. Program Pascasarjana Universitas Diponegoro. Semarang.

Ghanimata, F. dan K. Mustafa. 2012. Analisis

Pengaruh Harga, Kualitas Produk dan Lokasi terhadap Keputusan Pembelian (Studi pada Pembeli Produk Bandeng Juwana Elrina Semarang). Undergraduate Thesis. Fakultas Ekonomika dan Bisnis. Universitas Diponegoro. Semarang.

Heizer, J. dan B. Render. 2006. Manajemen Produksi. Salemba Empat. Jakarta.

Husein, U. 2005. Metode Penelitian. Salemba Empat. Jakarta.

Kotler, P. 2000. Prinsip-Prinsip Pemasaran Manajemen. Prenhalindo. Jakarta.

Kotler, P. dan Keller, K.L. 2012. Manajemen Pemasaran Jilid I Edisi ke 12. Erlangga. Jakarta.

Mursid, M. 2014. Managemen Pemasaran. Bumi Aksara. Jakarta.

Roidah, I. S. 2014. Pemanfaatan Lahan dengan Menggunakan Sistem Hidroponik. Bonorowo. 
Jurnal Universitas Tulungagung. Vol 1 (2): 43-50.

Rosliani, R dan N. Sumarni. 2005. Budidaya Tanaman Sayuran dengan Teknik Hidroponik. Balai Penelitian Tanaman Sayuran Pusat Penelitian dan Pengembangan Hortikultura Badan Penelitian dan Pengembangan Pertanian.

Sugiyono. 2014. Metode Penelitian Kuantitatif, Kualitatif, dan Kombinasi (Mixed Methods). Alfabeta. Bandung.

Siregar, S. 2010. Statistika Deskriptif untuk Penelitian: Dilengkapi Perhitungan Manual dan Aplikasi SPSS Versi 17. Rajawali Press. Jakarta.

Tjiptono, F. 2007. Pemasaran Jasa. Banyumedia Publishing. Malang.

Wangko, M. C. 2013. Pengaruh Strategi Bauran Pemasaran terhadap Keputusan Pembelian Mobil Panther pada PT Astra Internasional-Izuzu Manado. Jurnal Emba. Vol. 1 (3): 446557. 